\title{
THE EFFECTS OF INWARD AND OUTWARD FDI ON DOMESTIC INVESTMENT: EVIDENCE USING PANEL DATA OF ASEAN-8 COUNTRIES
}

\author{
Bee Wah TAN ${ }^{1}$, Soo Khoon $\mathrm{GOH}^{2}$, Koi Nyen WONG \\ ${ }^{1,2}$ Centre for Policy Research and International Studies, \\ Universiti Sains Malaysia, 11800 Penang, Malaysia \\ ${ }^{3}$ Business School, Sunway University, 46150 Selangor, Malaysia \\ E-mails: ${ }^{1}$ bewahtan@gmail.com, ${ }^{2}$ skgoh@usm.my (corresponding author), \\ 3koinyenw@sunway.edu.my
}

Received 14 January 2015; accepted 27 October 2015

\begin{abstract}
In view of the changing FDI landscape, in particular, a drastic increase in outward FDI from developing and transition economies in recent years, this paper attempts to explore the possible impacts of outward FDI other than domestic savings and inward foreign direct investment on domestic investment. The major contribution of this study is that it is the first effort to empirically analyse the short- and long-run effects of the outward FDI using panel data of ASEAN-8 countries, which could provide useful policy implications for governments at both regional and international levels to achieve inclusive growth and sustainable development. Using pool mean group analysis, this paper finds that the gross domestic saving, inward FDI and outward FDI have a positive long-run impact on the gross domestic investment even though their long-run estimates are inelastic. The empirical study reveals that both inward FDI and outward FDI, to some extent, are complementary to the gross domestic investment.
\end{abstract}

Keywords: outward FDI, inward FDI, domestic investment, economic integration, multinationals, ASEAN, PMG.

JEL Classification: F21.

\section{Introduction}

As globalisation unfolds, the Association of Southeast Asian Nations (ASEAN) ${ }^{1}$ is increasingly operating as part of the global production networks. The progressive trade and investment links of ASEAN to the global economy are fundamentally attributable to the adoption of outward-looking development strategy ${ }^{2}$ by its member states. It is also well documented in the literature that further regional economic integration by establishing an ASEAN Economic Community (AEC) by 2015 could potentially boost higher

\footnotetext{
${ }^{1}$ Initially, the ASEAN's formation in 1967 was meant to resolve outstanding issues pertaining to political tensions and regional security e.g. the advancement of communism (Cheong, Wong 2006).

${ }^{2}$ For example, the liberalization of capital account, trade and investment agreements (see ASEAN Investment Report 2011).
} 
trade and investment flows for the region due to the potential of a market size of 600 million population from an integrated ASEAN. Moreover, the region's diversity ${ }^{3}$ may encourage both ASEAN and non-ASEAN multinational corporations (MNCs) to set up their production platforms within the region according member countries' comparative cost advantages and locational advantages ${ }^{4}$. Hence, foreign direct investment (FDI) is of central importance to value-adding activities in the region. However, the FDI landscape in ASEAN is changing, in particular, its outward FDI (OFDI) has been increasing sharply in recent years owing to efficiency-, market-, resource- and strategic asset-seeking reasons (ASEAN 2012). For instance, ASEAN as a region had been ranked as the third largest source of OFDI, amounting to US\$33 billion in 2007, and it rose by 80 per cent to US\$60 billion in 2011 (UNCTAD 2012). As of 2012, its total accumulated OFDI had reached approximately US\$66 billion. As stated by ASEAN Investment Report (2012), Singapore $^{5}$ is the leading source of OFDI among the ASEAN member states followed by Malaysia, Thailand and Indonesia. In general, the stated member states' OFDIs were on the upward trend since 2003 (see Fig. 1). On the other hand, the region's relatively smaller OFDI member states are the Philippines, Brunei Darussalam, Cambodia and Laos (UNCTAD 2013). Nevertheless, the OFDI from ASEAN declined in 1997/98 and 2008/09 due to the Asian financial crisis and the global debt crisis respectively.

In terms of the major sources of FDI in ASEAN by region, there are some notable trends as shown in Table 1. Firstly, the European Union (EU) was the traditional dominant outward direct investor in ASEAN followed by North America (i.e. USA and Canada) for the period 1995-2009, attributed to the movement of their international productions to ASEAN in order to remain competitive in the global production networks (see UNCTAD 2011). However, the rest of Asia, which mainly comprises China, India, Pakistan and the Republic of Korea, overtook the EU to become the largest source of outward direct investment in the region since 2010. Secondly, ASEAN firms turned out to be the second major outward direct investors in ASEAN starting in 2011, outdoing the EU and North America. The drop in the ranking of OFDI from the EU and North America in ASEAN since 2010 was due to the aftermath of the debt crisis in 2008/09 that caused their government-controlled entities to divest and redirect their OFDI back to their home regional economy (see UNCTAD 2011). Whereas there is a phenomenal increase OFDI from the rest of Asia as well as ASEAN in the region since 2010 owing to the AEC that promotes investment opportunities, and locational advantages to ASEAN member states (ASEAN 2014). Lastly, among the five regional economies shown in Table 1, Australasia (i.e. Australia and New Zealand) remained as the smallest contributor of FDI to the ASEAN region.

\footnotetext{
${ }^{3}$ According to Plummer (2009), the ASEAN diversity could create opportunities for production fragmentation by multinationals.

${ }^{4}$ Examples of locational advantages are availability of cheaper resources, proximity to market and favourable policy regime and etc.

${ }^{5}$ In the case of Singapore, there is evidence of an OFDI-led trade hypothesis, particularly with regard to merchandise exports and imports, which is an indication OFDI opens important channels for intrafirm trade activities, home country sourcing and backward integration (Wong, Goh 2011).
} 

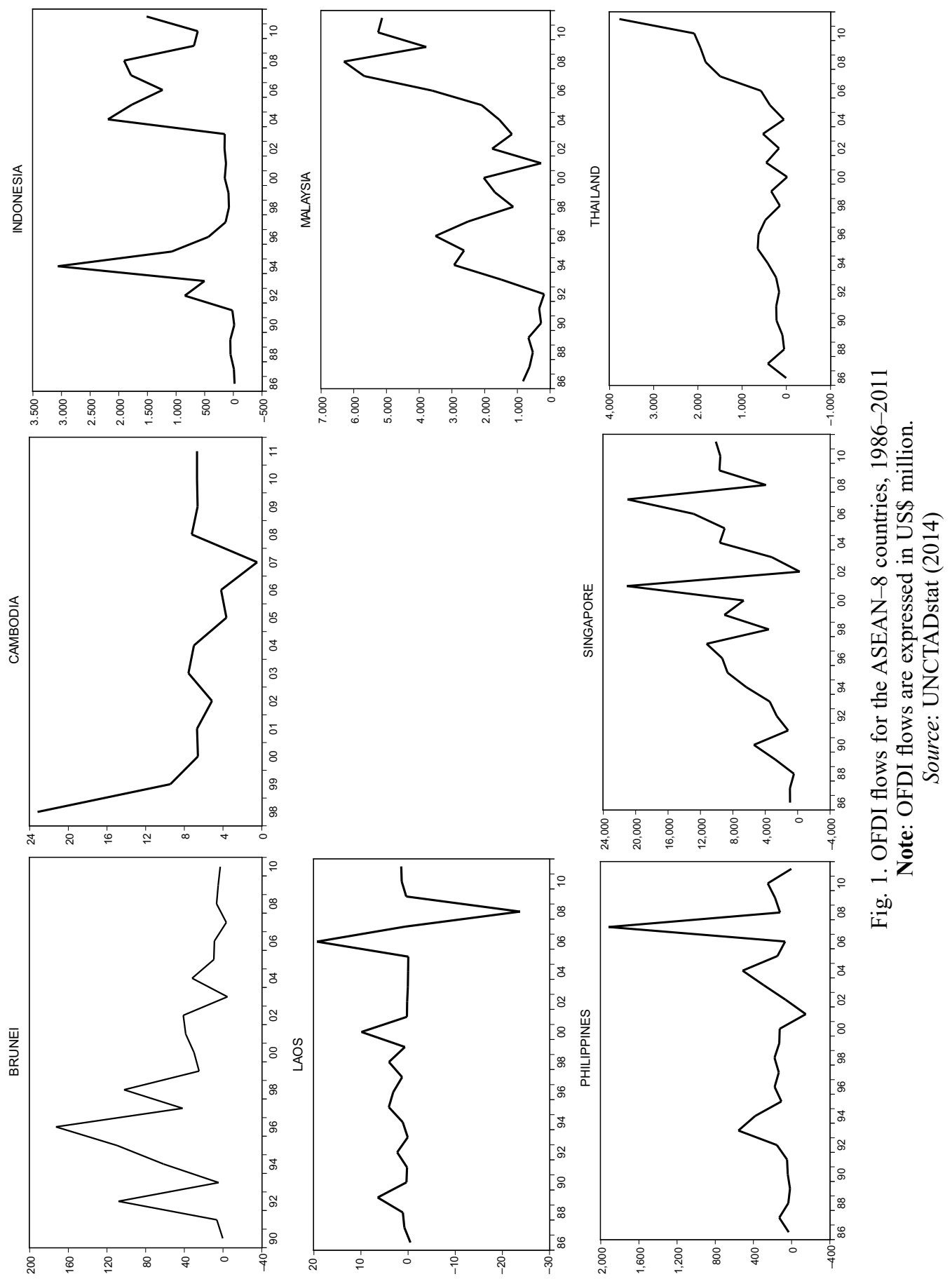
Table 1. Flows of inward FDI to ASEAN by ASEAN's dialogue partners**, 1995-2011, US\$ millions

\begin{tabular}{lccccc}
\hline \multicolumn{1}{c}{ Source countries } & $1995-99 *$ & $2000-04 *$ & $2005-09 *$ & 2010 & 2011 \\
\hline Intra-ASEAN & 3733.3 & 2765.4 & 7598.9 & 14290.5 & 17570.7 \\
\hline $\begin{array}{l}\text { Rest of Asia [China + India + Japan + } \\
\text { Pakistan + Republic of Korea] }\end{array}$ & 5058.5 & 3734.5 & 10908.7 & 20906.1 & 21823.4 \\
\hline European Union (EU) 27 & 6820.8 & 9096.6 & 13273.5 & 17403.1 & 17172.6 \\
\hline North America [USA + Canada] & 5152.6 & 3713.0 & 5680.4 & 13727.6 & 7081.3 \\
\hline Australasia [Australia + New Zealand] & 13.9 & 82.7 & 1117.8 & 2603.4 & 1336.1 \\
\hline
\end{tabular}

Notes: $*$ Denotes average figures; $* *$ Net FDI $=$ Equity + Net Inter - company Loans + Reinvested Earnings.

Source: ASEAN Secretariat - ASEAN FDI Database as of 11 July 2012. Data is compiled from submission of ASEAN Central Banks and National Statistical Offices through the ASEAN Working Group on FDI Statistics.

The upward trend of ASEAN's OFDI poses an imperative empirical question pertaining to the possible impacts of the region's OFDI on its domestic investment since ASEAN as a whole aims to grow its global production network, on one hand, and to expand the business investment opportunities for its domestic firms (e.g. small- and medium-sized local suppliers), on the other hand, in the era of globalisation. By and large, there are two views concerning the economic relationship between OFDI and domestic investment. The first view argues that OFDI is seen as a substitute for domestic investment when domestic production has been relocated abroad due to diminished domestic investment opportunities (Stevens, Lipsey 1992). While the second view contends that an increase in OFDI activities by home country multinationals may promote higher domestic investment as foreign affiliates use home inputs to produce outputs in the host country (Desai et al. 2005).

This paper intends to explore and study the possible impacts of domestic saving (DS), inward FDI (IFDI), and OFDI on domestic investment for the eight ASEAN member states based on the theoretical model developed by Feldstein (1995), which is an extension of the well-known Feldstein and Horioka (1980) model examining the relationship between saving and investment among Organisation for Economic Co-operation and Development (OECD) countries during the 1960s and 1970s. The major contribution of this study is that it is the first effort to empirically analyse the short- and long-run impacts of ASEAN's OFDI on its domestic investment using panel data of ASEAN-8 countries. In view of domestic investment is an important source of the region's economic development, the empirical study of the substitution (complementary) effect of the region's OFDI to its domestic investment is pertinent especially in the formulation of outward-oriented development policies. Given the ASEAN is a heterogeneous region, which comprises member countries with differing sizes, levels of economic development and governance system, the current study employs the dynamic panel data analysis. This data analytical approach takes explicitly into account the heterogeneity of each cross-sectional units by allowing for individual-specific effects and hence, more reliable and more efficient estimates (Davidson, MacKinnon 2004). Apart from dealing 
with both time series and cross section properties of the data, it has the advantage of improving the statistical properties of estimates when the number of observations over time is limited, especially when annual data are used for ASEAN countries. This paper will then use Pooled Mean Group estimator (PMG) to explore the impact of OFDI on domestic investment among ASEAN-8 countries. This particular estimator allows us to deal with heterogeneity problem by allowing the short-run coefficients and error variances to differ across countries but assuming homogeneity of the long-run coefficient by pooling countries over the long-run (Pesaran et al. 1999). The PMG estimate of the Autoregressive Distributed Lag (ARDL) regression model yield consistent coefficients despite the possible presence of endogeneity because it includes lags of dependent and independent variables (Pesaran et al. 1999). Pesaran and Shin (1999) stated that panel ARDL can be used when the variables are with different order of integration, no matter whether the variables are $I(0)$ or $I(1)$.

The rest of this paper is organised as follows. Section 1 reviews the empirical studies on OFDI and domestic investment. Section 2 presents the theoretical framework, data and methodology intended for this study. Section 3 analyses and discusses the empirical findings, followed by the main conclusions with policy implications in the last Section.

\section{Review of the literature}

In view of the drastic increase in OFDI from both the developing and transition economies in recent years, there are studies examining how would OFDI impact on domestic investment since the latter is also an important source of economic growth. Steven and Lipsey (1992) contended that OFDI could have an adverse effect on domestic investment via two important channels, namely, domestic financial markets and product markets. In the case of the first channel, if domestic firms were to increase their multinational activities in the region e.g. due to market-seeking reason, the increase in FDI outflows could diminish domestic investment especially their multinational activities are not being financed externally. Hence, OFDI can also detract domestic investment via the second channel when domestic production has been relocated entirely abroad (e.g., domestic firms want seek better access to foreign market). As a result, OFDI displaces exports, which in turn substitutes domestic investment. However, the economic relationship between OFDI and domestic investment could be complementary if the domestic firms' cross-border direct investment is to take advantage of cheaper factors of production in the host economies (see Goh et al. 2013). Consequently, intra-firm trade activities or home sourcing activities open an important channel to boost export trade, which may have positive effect on domestic investment.

The review of the empirical literature on the impact of OFDI on domestic investment is mixed. Some studies reveal the substitutional effect of OFDI on domestic investment (see Steven, Lipsey 1992; Feldstein 1995; Anderson, Hainaut 1998; Kim 2000; Desai et al. 2005; Sauramo 2008; Girma et al. 2010; Al-Sadiq 2013; Goh, Wong 2014). In particular, Feldstein (1995) found that each dollar of outbound FDI reduces domestic investment by approximately one dollar for OECD countries. Similar to the finding 
of Feldstein (1995), OFDI tends to reduce domestic investment in the United States, Japan, Germany and the United Kingdom (Anderson, Hainaut 1998). In addition, the empirical evidence that supports the proposition of the substitutional effect of OFDI can also be found in OECD countries (Feldstein 1995; Desai et al. 2005), 121 developing and transitional economies (Al-Sadiq 2013), Finland (Sauramo 2008), Malaysia (Goh, Wong 2014), the American multinational firms (Steven, Lipsey 1992; Desai et al. 2005), the Indian multinational corporations (Girma et al. 2010) and the Korean multinational (Kim 2000).

Conversely, there were also studies advocating the complementary effect of OFDI on domestic investment or output. For instance, Stevens and Lipsey (1992), Hejazi and Pauly (2003), Desai et al. (2005) and Herzer and Schrooten $(2008)^{6}$ found that domestic investment did respond positively to an increase in OFDI activities. For instance, Herzer and Schrooten (2008) argued that OFDI could have a positive influence on domestic investment especially multinational firms are able to combine home production with foreign production to reduce costs and thus, raise the return of domestic production, which in turn raises domestic investment. Using evidence from the Netherlands, Goedegebuure (2006) found that internationalisation activities were instrumental in promoting domestic R\&D specifically in both high-tech and low-tech industries. The positive impact of a firm's OFDI on its domestic R\&D spending was supported by an empirical study using panel data on the Taiwanese manufacturing firms (Chen, Yang 2013). In addition, it was also found that OFDI could have a complementary effect on domestic output or performance based on fourteen industrialised countries (Herzer 2008) and a panel of Italian firms investing abroad (Imbriani et al. 2011).

By and large, the mixed empirical evidence pertaining to the economic relationship between OFDI and domestic investment could be caused by the type of data used such as cross-country data, country- and firm-level time-series data. Cross-country studies suffer from a major weakness where they implicitly assume that the panel countries are similar in economic structures and are at the same stage of economic development. As pointed out by Desai et al. (2005: 9), the cross sectional evidence may be confounded by omitted variables. Hence, this study fills up the literature gaps by exploring the impact of OFDI on domestic investment for the ASEAN-8 countries.

\section{Model specification, data and estimation method}

\subsection{Model specification}

The present paper examines the possible impacts of DS, IFDI and OFDI on domestic investment in the ASEAN-8 countries based on Feldstein's (1995) theoretical model, which is an extension of Feldstein and Horioka's (1980) model (hereafter F-H model). The F-H model can be derived using the Absorption Approach, which explains that the

\footnotetext{
${ }^{6}$ Applying the cointegrating techniques, Herzer and Schrooten (2008) found that there was a complementary relationship between OFDI from Germany and its domestic investment in the short-run. While in the long-run, the effect of OFDI on domestic investment is substitutional.
} 
balance of trade is the difference between an economy's total output and its absorption represented by consumption $(C)$, investment $(I)$ and government spending $(G)$. The national output $(Y)$ identity can be written as:

$$
Y_{t}=C_{t}+I_{t}+G_{t}+X_{t}-M_{t},
$$

where $X_{t}$ and $M_{t}$ are exports and imports respectively.

Alternatively, equation (1) can be expressed as:

$$
Y_{t}-C_{t}-G_{t}=I_{t}+X_{t}-M_{t}
$$

Substitute national saving $\left(S_{t}\right)$ for $Y_{t}-C_{t}-G_{t}$ and current account balance $\left(C A_{t}\right)$ for $\left(X_{t}-M_{t}\right)$ in equation (2), we have:

$$
S_{t}=I_{t}+C A_{t}
$$

There exists a $C A$ identity (i.e. $C A_{t}=-F A_{t}$ ) where $F A_{t}$ is financial account balance, which is the difference between foreign assets and domestic assets (e.g. FDI) owned by domestic residents and foreigners respectively.

Therefore, equation (3) becomes:

$$
I_{t}=S_{t}+F A_{t} .
$$

According to the $\mathrm{F}-\mathrm{H}$ model, if there is perfect capital mobility, we expect a low correlation between $I_{t}$ and $S_{t}$. Given that $I F D I_{t}$ and $O F D I_{t}$ constitute in $F A_{t}$, we have:

$$
I_{t}=S_{t}+I F D I_{t}+O F D I_{t}
$$

Hence, the final $\operatorname{model}^{7}$ for the empirical analysis is written as follows:

$$
\frac{G D I}{G D P}=a+b\left[\frac{G D S}{G D P}\right]+c\left[\frac{I F D I}{G D P}\right]+d\left[\frac{O F D I}{G D P}\right]+u,
$$

where GDI is real gross domestic investment, GDS is real gross domestic saving, GDP is real gross domestic product, IFDI is real inward FDI, OFDI is real OFDI, and $u$ is a stochastic disturbance. Since taking logarithmic transformation can linearise the model and make elasticity calculations easier as the estimated coefficients are approximate to the percentage changes in variables (Gujarati, Porter 2008), the model can be rewritten as:

$$
L G D I_{i t}=\beta_{0}+\beta_{1} L G D S_{i t}+\beta_{2} L I F D I_{i t}+\beta_{3} L O F D I_{i t}+\varepsilon_{i t},
$$

where $L$ denotes the natural logarithm and $\varepsilon_{i t}$ is the residuals.

\subsection{Data}

The sample period and the sample choice of the ASEAN countries are entirely based on availability of data for each variable of interest. Owing to the unavailability of some data, we excluded Myanmar and Vietnam from the sample. Hence, our sample countries are restricted to eight instead of the ten ASEAN countries, which spans annually from

\footnotetext{
${ }^{7}$ This model has been adopted for empirical studies by Desai et al. (2005), Sauramo (2008), and Goh and Wong (2014).
} 
1986-2011. The eight ASEAN countries are Brunei Darussalam, Cambodia, Indonesia, Lao, Malaysia, the Philippines, Singapore and Thailand. The proxy variable for GDI is gross fixed capital formation (GFCF). Its data source for GFCF and GNS are obtained from the World Bank, World Development Indicators and Global Development database. While both IFDI and OFDI data can be retrieved from United Nation Conference on Trade and Development (UNCTAD), Division on Investment and Enterprise database. All the variables are seasonally adjusted and are expressed in constant US dollar $(2000=100)$ before being transformed into logarithmic terms.

\subsection{Estimation method}

\section{Panel unit root tests}

Firstly, the panel unit root tests proposed by Levin et al. (2002) (LLC) and Im et al. (2003) are utilised in our analysis. The LLC test possesses good power when autoregressive roots are identical over the cross sections (Maddala, Wu 1999). Specifically, the LLC test is:

$$
\Delta y_{i t}=\alpha_{i}+\delta_{i} y_{i t-1}+\sum_{j=1}^{P_{i}} P_{i} \Delta y_{i t-j}+\varepsilon_{i t},
$$

where $\Delta$ is the first difference operator, $y_{i t}$ represents the series of observations for individual country, $i$, with time period $t=1,2, \ldots, T$. The series are assumed to be stationary under the null hypothesis of $H_{0}: \delta_{i}=\delta=0$ for all countries against the alternative $H_{1}=\delta_{i}=\delta<0$ for all countries, $i$. Levin et al. (2002) added that $\delta$ is homogenous across all regions of the panel and the LLC test is based on the $t$-statistics of the estimator and thus, provides higher power than individual observation unit root estimation.

Moreover, the IPS test developed by Im et al. (2003) applied the same model used in LLC test and is based on the mean of individual unit root statistics. The advantage of IPS test is that it is less restrictive and more powerful than LLC test. The IPS test provides a solution to Levin and Lin's serial correlation problem by assuming heterogeneity between units in a dynamic panel framework. The IPS test is written as follows:

$$
\Delta y_{i, t}=\alpha_{i}+\rho_{i} y_{i, t-1}+\sum_{j=1}^{p} \phi_{i j} \Delta y_{i, t-j}+\varepsilon_{i, t} ; i=1,2, \ldots, N ; t=1,2, \ldots, T,
$$

where $y_{i, t}$ is specified as each variable under the consideration of the model, $\alpha_{i}$ represents the individual fixed effect and $\rho$ is chosen to create the residuals uncorrelated over time. The null hypothesis of the IPS test is $H_{0}: p_{i}=0$ for all $i$ against the alternative hypothesis $H_{1}: p_{i}<0$ for some $i=1, \ldots, N_{1}$ and $\rho_{i}=0$ for $i=N_{1}+1, \ldots, N$. The IPS statistic is based the Augmented Dickey-Fuller (ADF) statistics averaged across the group and is written as:

$$
\bar{t}=\frac{1}{N} \sum_{i=1}^{N} t_{i T},
$$

where $t_{i t}$ denotes as the ADF $t$-statistic for country $i$ based on the country-specific ADF regression in Equation (7). The $\bar{t}$ statistic has been shown to be approximately normally distributed under the null hypothesis. 


\section{Mean Group (MG) and Pooled Mean Group (PMG) Estimators}

After establishing the order of integration of each variable in Equation (7), the Mean Group (MG) and Pooled Mean Group (PMG) estimator will be used to estimate the statistical analysis of the dynamic panel data.

Mean Group (MG)

The MG estimator provides consistent estimates of the long-run coefficient by separating the regressions estimation for each country and computing the averages of the country-specific coefficients (Pesaran, Smith 1995). For example, it assumes that an ARDL is a follows:

$$
a_{i}(L) y_{i t}=b_{i}(L) x_{i t}+d_{i} z_{i t}+e_{i t} \text {. }
$$

For country $i$, where $i=1, \ldots, N$, then the long-run parameters for country $i$ is:

$$
\theta_{i}=\frac{b_{i}(1)}{d_{i}(1)}
$$

whereas the MG estimator for the whole panel will be specified by:

$$
\theta=\frac{1}{N} \sum_{i=1}^{N} \hat{\theta}_{i}
$$

Pesaran et al. (1999) asserted that the sufficiently high lag order in the MG estimation equation yields super-consistent estimators of the long-run parameters even when the regressors are $I(1)$. These assumptions are quite powerful as it requires that the groupspecific parameters are distributed independently of the regressors, which are strictly exogenous.

\section{Pooled Mean Group (PMG)}

The PMG method of estimation developed by Pesaran et al. (1999) is employed to allow an intermediate position between the MG methods. The PMG estimation allows for country-specific short-term adjustments and convergence speeds, while imposing cross-country homogeneity restrictions only on the long-run coefficient (see Pesaran et al. 1999). Hence, the PMG estimation has the advantages to determine the long-run and short-run dynamic relationships. To be more precisely, the unrestricted specification for the ARDL system of equations for $i=1,2, \ldots, T$ time periods and $i=1,2, \ldots$, $N$ countries for the dependent variable $y$ is:

$$
y_{i t}=\sum_{j=1}^{m} \lambda_{i j} y_{i, t-j}+\sum_{j=0}^{n} \delta_{i j}^{\prime} x_{i, t-j}+\mu_{i}+\varepsilon_{i t},
$$

where $x_{i j}$ is the $(k \times 1)$ vector of explanatory variables for group $i$ and $\mu_{i}$ represents the fixed effects. This model can be re-parameterised as a VECM system:

$$
\Delta y_{i t}=\theta_{i}\left(y_{i, t-1}-\beta_{i}^{\prime} x_{i, t-1}\right)+\sum_{j=1}^{m-1} \gamma_{i j} \Delta y_{i, t-j}+\sum_{j=0}^{n-1} \gamma_{i j}^{\prime} x_{i, t-j}+\mu_{i}+\varepsilon_{i t},
$$

where $\beta^{\prime}$ s are the long-run parameters and $\theta_{i}$ s are the error correction parameters. The 
pooled group restriction is that the elements of $\beta$ are common across countries, so that:

$$
\Delta y_{i t}=\theta_{i}\left(y_{i, t-1}-\beta_{i}^{\prime} x_{i, t-1}\right)+\sum_{j=1}^{m-1} \gamma_{i j} \Delta y_{i, t-j}+\sum_{j=0}^{n-1} \gamma_{i j}^{\prime} x_{i, t-j}+\mu_{i}+\varepsilon_{i t} .
$$

The PMG estimator allows for heterogeneous short-run coefficients yet constrains longrun parameters to be the same across unit, i.e. $\theta_{i}=\theta$. The maximum likelihood is a preferred method of estimating the parameters of this model and it yields consistent and asymptotic estimate under some regularity assumption of the estimator. Thus, both MG and PMG estimations are required to select the appropriate lag length for the individual country equations using the Akaike Information Criterion (AIC). This procedure considers all possible lag orders on all variables and selects the specification with the best AIC value.

Finally, as noted by Pesaran and Smith (1995), the potential threat of inefficiency and inconsistency, the assumption of long-run homogeneity (i.e. under the null hypothesis, there is no significant difference between MG and PMG estimates of long-run coefficients) will be tested using the Hausman (1978) test (hereafter referred to as $h$ test). If the parameters are homogenous, the PG estimator will be more efficient than MG.

\section{Empirical results}

\subsection{Panel unit root tests}

The panel unit root tests are performed before running the MG and PMG analysis of the panel data. The unit root test results suggest that LGDI, LIFDI and LOFDI are nonstationary in level with and without trend ${ }^{8}$. However, both tests indicate that $L G D S$ is non-stationary (i.e. $I(1))$ in level with trend, but is stationary $(I(0))$ in level without trend. Thus, the unit root tests for $L G D S$ is inconclusive. Despite the mixed unit root test results, as pointed out by Kim et al. (2010) and Iwata et al. (2011), the MG and PMG estimation of an ARDL regression provides consistent estimators irrespective of whether the variables are $I(0)$ or $I(1)$ if there exists a unique vector defining the long-run relationship among variables with suitable lag order chosen.

\subsection{The MG and PMG estimation results}

Prior to estimating using the MG and PMG estimation methods, the lag length of the estimated the models can be determined by the AIC and Schwarz Bayesian Criterion (SBC). Given the limited sample size, a maximum lag length of two is imposed on the models. Both lag length selection criteria suggest that the ARDL $(1,1,1,1)$ is the most adequate for all countries. Table 2 shows the estimates by MG and PMG as well as the Hausman test results. Since the joint Hausman test cannot reject the null hypothesis of the absence of the long-run heterogeneity (i.e. there is no significant difference between MG and PMG estimates of long-run coefficients), the estimated coefficients in

\footnotetext{
${ }^{8}$ Due to space constraint, the results for the panel unit root tests are available upon request from the authors.
} 
natural logarithm by the PMG appear consistent and efficient in comparison to the MG estimates and they can used for elasticity analysis in the short-run and long-run. Given that the error-correction estimates are significantly negative for MG and PMG estimators (refer to Panel A and B in Table 2), the findings confirm there exists a long-run relationship among $L G D I$ and its determinants ( $L G D S, I F D I$ and $O F D I$ ). The speed of adjustment to its long-term relation is about 2 years and 4 months.

Specifically, the PMG estimates show that $L G D S, L I F D I$ and $L O F D I$ are significantly positive related to $L G D I$. The estimated effect of GDS on GDI implies that a $1 \%$ point increase in GDS would generate $0.35 \%$ increase in GDI. The estimation results also show that a $1 \%$ point increase in IFDI and OFDI would result in a $0.1 \%$ and $0.06 \%$ increase in GDI respectively, suggesting that the long-run estimates are inelastic. The evidence of the complementary relationship between OFDI and GDI corroborates the empirical studies by Hejazi and Pauly (2003), Goedegebuure (2006), Herzer and Schrooten (2008), Imbriani et al. (2011) and Chen and Yang (2013).

As discussed in Section 2, the short-run coefficients using the PMG approach are not restricted to be the same across countries. As a result, we do not have a single pooled estimate for each coefficient. It is interesting to note that the estimated short-run coefficients by the PMG estimator are not significant, implying there is no short-run relation between GDI and its key explanatory variables such as GDS, IFDI and OFDI.

The robustness of the PMG model for the ASEAN-8 member states have been confirmed by several diagnostic tests as presented in Panel C, Table $2^{9}$. The BreuschGodfrey test reveals that the residuals are not serially correlated. The Jarque-Bera (JB) statistics suggest that the disturbances of the regressors are normally distributed. The Ramsey RESET test statistics indicates the model is correctly specified. Lastly, the autoregressive conditional heteroscedasticity $(\mathrm{ARCH})$ test suggests that the disturbance term in the equation is homoscedastic. Pesaran et al. (1999) asserted that the stability of the estimated coefficient of the error correction model should be graphically investigated. In view of this, we apply the Cumulative Sum (CUSUM) and the Cumulative Sum of Square (CUSUMSQ) tests, which were developed by Brown et al. (1975). The estimated coefficient proves to be stable if the plot of the CUSUM statistics stays within 5\% significant levels. The country-specific graphical presentation of CUSUM test is presented in Panel D, Table 2. Besides, similar procedure is used to carry out the CUSUMSQ test that is based on the squared recursive residuals. The country-specific graphical presentations of the CUSUMSQ test are provided can be found in Panel E, Table $2^{10}$.

\footnotetext{
${ }^{9}$ The findings of the diagnostic test were performed by averaging the country specific diagnostic statistics of the ASEAN-8 countries. These PMG diagnostic tests were carried by using the program written in GAUSS. The original data and GAUSS code are available on Pesaran's web site: http://www.econ.cam.ac/uk/faculty/pesaran.

${ }^{10}$ The country specific estimation results are available upon request from the authors.
} 


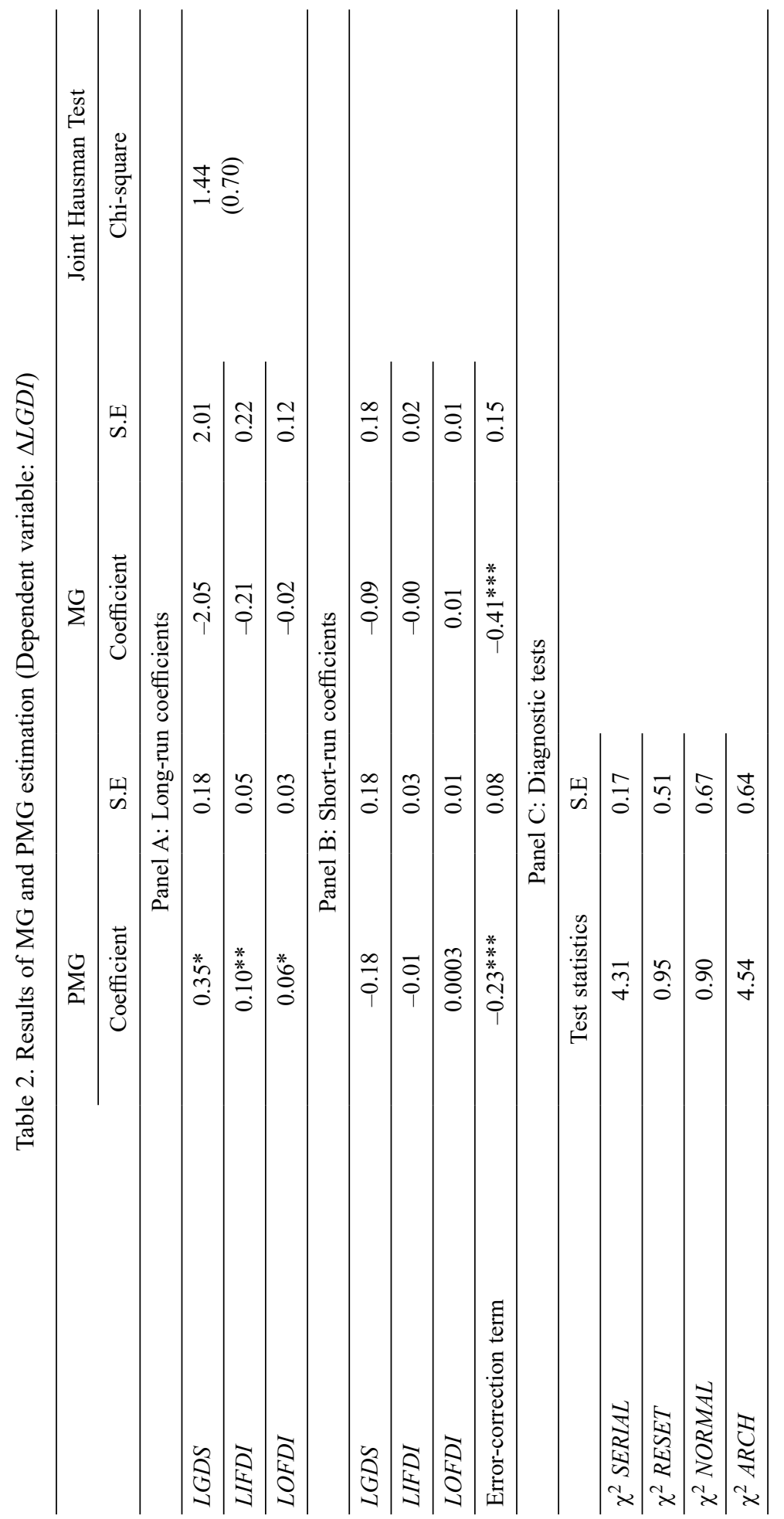




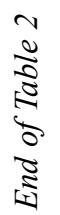
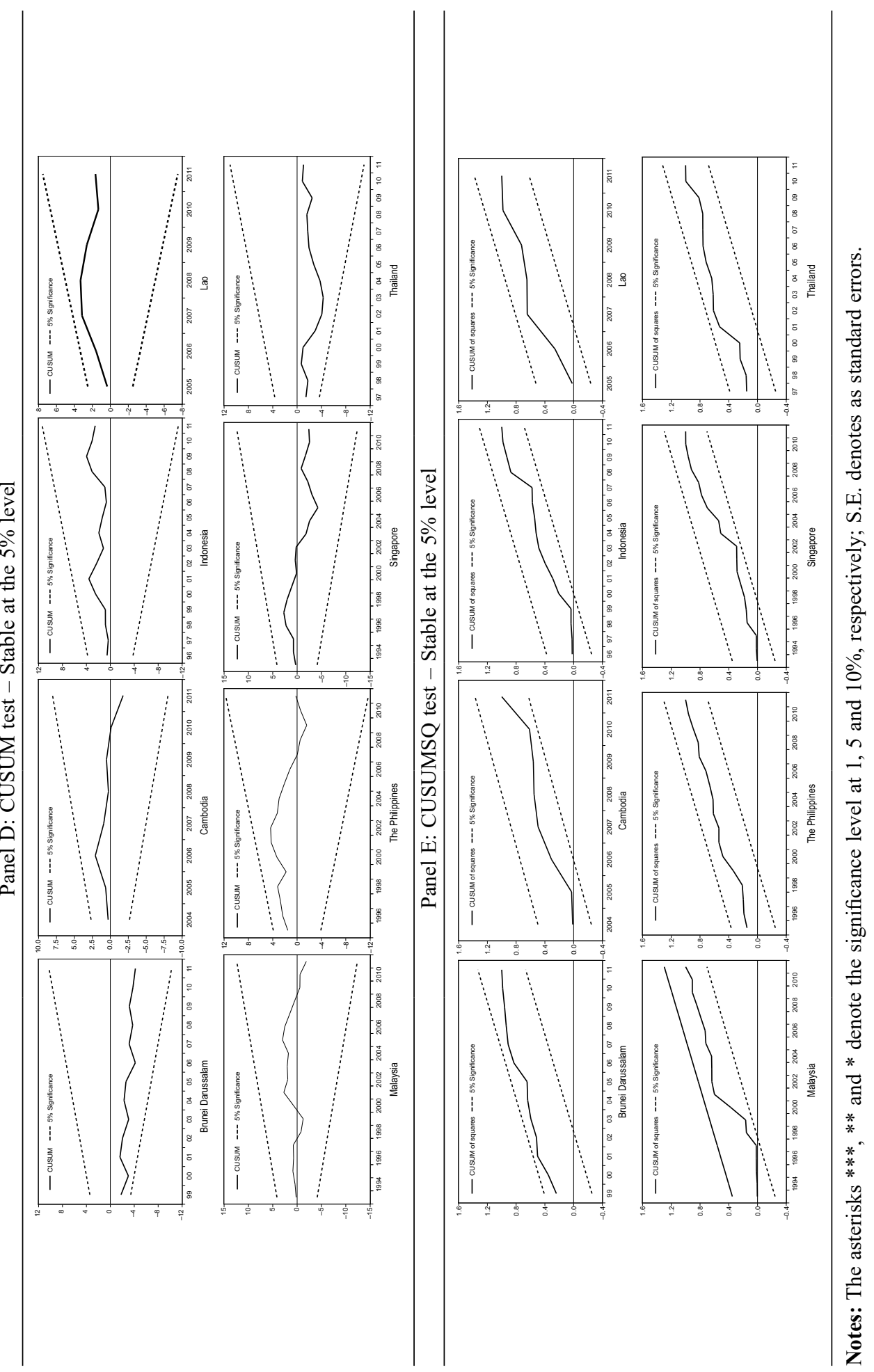


\section{Conclusions and policy implications}

According to the AEC Blueprint, the participation in the global production networks is an important economic agenda for the economies of ASEAN member states ahead of realising the AEC in 2015. In turn, the domestic firms of all sizes should capitalise on the globalisation through IFDI and OFDI channels in order to stimulate domestic investment, intra- and inter-firm trade. The upward trend of cross-border direct investment by ASEAN multinationals poses an interesting empirical question pertaining to the effect of OFDI on domestic investment as the latter macroeconomic variable is still an important source of economic growth and development for the region. This paper aims to ascertain whether there is a long-run relationship between GDI and its key determinants, viz. GDS, IFDI and OFDI based Feldstein's theoretical model using country-level panel data from the ASEAN-8 countries from 1986-2011. Applying the PMG estimation method, which has the advantage of yielding consistent and efficient estimates for long-run coefficients for elasticity analysis, the findings suggest that GDS, IFDI and OFDI have a positive long-run impact on GDI. Despite the long-run estimates are inelastic, the empirical study implies that both IFDI and OFDI, to some extent, are complementary to GDI for the ASEAN-8 countries. However, there is no evidence of any short-run relationship among these macroeconomic variables.

Broadly speaking, the findings in this paper can provide useful policy implications for the ASEAN governments as well as the emerging economies from other regions to achieve inclusive growth and sustainable development. As we know, the ASEAN as a region is diverse in terms of the comprehensiveness of liberalisation. The evidence of low positive long-run elasticity of GDI with respect to IFDI as well as OFDI implies that the ASEAN governments should pursue more liberal FDI policies to encourage FDI inflows as well as outflows. The liberal policies on IFDI is instrumental in increasing gross capital formation and facilitating technology transfer that can potentially stimulate domestic firms' investment. Apart from allowing greater foreign participation in the regional economy, the regional governments should encourage more joint ventures between domestic firms with foreign firms in order to promote domestic investment. Moreover, the less developed economies in ASEAN should allocate a higher proportion of the government budget to increase spending on infrastructure to attract FDI inflows. Liberal policies towards OFDI could encourage more outward cross-border direct investment by potential ASEAN firms in the long-run, which has the advantage of internationalising their business activities abroad so that they can be part of the global supply chains. And these OFDI activities are also expected to have a positive impact GDI through intra- and inter-firm trade. The evidence of the weak complementary relationship between OFDI and GDI also suggests a need for policy makers to further deepen the integration relationship with the aim of boosting regional investment activities. For instance, the ASEAN governments should be more active in their efforts to promote outward investment by introducing double taxation agreement and provide outward investment incentive such as investment guarantees.

Even though the PMG estimator could yield robust results, the main limitation of this empirical study is that the pooled sample countries are being restricted to eight ASEAN 
countries instead of representative ten member states because the scarce data for Myanmar and Vietnam. One likely area of future research is to extend the current study to cover ASEAN plus Three such as China, Japan and South Korea, which is important because ASEAN plus Three adopted outward-looking policies to internationalise their economies, which may have policy implications on domestic investment and FDI flows in the era of globalisation.

\section{Acknowledgements}

This work was supported by a research grant 1001/CDASAR/816277 from Universiti Sains Malaysia.

\section{References}

Al-Sadiq, A. 2013. Outward FDI and domestic investment: the case of developing countries, Working Paper, No.WP/13/52. International Monetary Fund (IMF).

Anderson, P. S; Hainaut, P. 1998. Foreign direct investment and employment in the industrial countries, Working Paper, No.61. Bank for International Settlements (BIS).

ASEAN. 2011. ASEAN investment report 2011: sustaining FDI flows in a post-crisis world. ASEAN Secretariat, Jakarta.

ASEAN. 2012. ASEAN investment report 2012: the changing FDI landscape. ASEAN Secretariat, Jakarta.

ASEAN. 2014. ASEAN investment report 2013-2014: FDI development and regional value chains. ASEAN Secretariat, Jakarta

Brown, R. L.; Durbin, J.; Evans, J. M. 1975. Techniques for testing the constancy of regression relationships over time, Journal of the Royal Statistical Society, Series B (Methodological) 37: 149-192.

Chen, K. M.; Yang, S. F. 2013. Impact of outward foreign direct investment on domestic R\&D activity: evidence from Taiwan's multinational enterprises in low-wage countries, Asian Economic Journal 27: 17-38. http://dx.doi.org/10.1111/asej.12000

Cheong, K. C.; Wong, C. K. 2006. Asia resurgent: transformation, growth and integration. Kuala Lumpur: University of Malaya Press.

Davidson, R.; MacKinnon, J. G. 2004. Econometric theory and methods. Oxford: Oxford University Press.

Desai, M. A.; Foley, C. F.; Hines, J. R. 2005. Foreign direct investment and the domestic capital stock, American Economic Review 95: 33-38. http://dx.doi.org/10.1257/000282805774670185

Feldstein, M.; Horioka, C. 1980. Domestic savings and international capital flows, Economic Journal 90(358): 314-329. http://dx.doi.org/10.2307/2231790

Feldstein, M. 1995. The effect of outbound foreign direct investment on the domestic capital stock, Chapter 2 in M. Feldstein, J. R. Hines, R. G. Hubbard (Eds). The effects of taxation and multination corporations. Chicago: University of Chicago Press, 43-66.

Girma, S.; Patnaik, I.; Shah, A. 2010. The impact of outbound FDI on domestic investment, NIPFP-DEA Research Program [online], [cited 3 February 2013]. Available from Internet: https://macrofinance.nipfp.org.in/PDF/02_6Pr_Patnaik_GPS2010_version3.pdf

Goedegebuure, R. 2006. The effects of outward foreign direct investment on domestic investment, Investment Management and Financial Innovations 3: 9-22. 
Goh, S. K.; Wong, K. N. 2014. Could inward FDI offset the substitution effect of outward FDI: evidence from Malaysia, Prague Economic Papers 2014: 413-425.

Goh, S. K.; Wong, K. N.; Tham, S. Y. 2013. Trade linkages of inward and outward FDI: evidence from Malaysia, Economic Modelling 35: 224-230.

http://dx.doi.org/10.1016/j.econmod.2013.06.035

Gujarati, D.; Porter, D. 2008. Basic econometrics. 4th ed. Boston, MA: McGraw-Hill Irwin.

Hausman, J. A. 1978. Specification tests in economics, Econometrica 46: 1251-1272.

http://dx.doi.org/10.2307/1913827

Hejazi, W.; Pauly, P. 2003. Motivations for FDI and domestic capital formation, Journal of International Business Studies 34: 282-289. http://dx.doi.org/10.1057/palgrave.jibs.8400030

Herzer, D.; Schrooten, M. 2008. Outward FDI and domestic investment in two industrialized countries, Economic Letters 99: 39-143. http://dx.doi.org/10.1016/j.econlet.2007.06.014

Herzer, D. 2008. The long-run relationship between outward FDI and domestic output: evidence from panel data, Economic Letters 100: 146-149. http://dx.doi.org/10.1016/j.econlet.2007.12.004

Im, K. S.; Pesaran, M. H.; Shin, Y. 2003. Testing for unit roots in heterogeneous panels, Journal of Econometrics 115: 53-74. http://dx.doi.org/10.1016/S0304-4076(03)00092-7

Imbriani, C.; Pittiglio, R.; Reganati, F. 2011. Outward foreign direct investment and domestic performance: the Italian manufacturing and services sectors, Atlantic Economic Journal 39: 369-381. http://dx.doi.org/10.1007/s11293-011-9285-z

Iwata, H.; Okada, K.; Samreth, S. 2011. A note on the environmental Kuznets curve for $\mathrm{CO}_{2}$ : a pooled mean group approach, Applied Energy 88: 1986-1996.

http://dx.doi.org/10.1016/j.apenergy.2010.11.005

Kim, D. Y.; Lin, S. C.; Suen, Y. B. 2010. Dynamic effects of trade openness on financial development, Economic Modelling 27: 254-261. http://dx.doi.org/10.1016/j.econmod.2009.09.005

Kim, S. J. 2000. Effects of outward foreign direct investment on home country performance: evidence from Korea, Chapter 10 in T. Ito, A. O. Krueger (Eds.). The role of foreign direct investment in East Asian economic development. Chicago: University of Chicago Press, 295-317.

Levin, A.; Lin, C. F.; Chu, C. S. J. 2002. Unit root tests in panel data: asymptotic and finite-sample properties, Journal of Econometrics 108: 1-24. http://dx.doi.org/10.1016/S0304-4076(01)00098-7

Maddala, G. S.; Wu, S. W. 1999. A comparative study of unit root tests with panel data and a new simple test, Oxford Bulletin of Economics and Statistic 61: 631-652.

http://dx.doi.org/10.1111/1468-0084.61.s1.13

Pesaran, H.; Smith, R. P. 1995. Estimating long-run relationships from dynamic heterogeneous panels, Journal of Econometrics 68: 79-113. http://dx.doi.org/10.1016/0304-4076(94)01644-F

Pesaran, H.; Shin, Y. C. 1999. An autoregressive distributed-lag modelling approach to cointegration analysis, Chapter 4 in S. Strøm (Ed.). Econometrics and economic theory in the 20th century, The Ragnar Frisch Centennial Symposium. Cambridge: Cambridge University Press, 371-413.

Pesaran, H.; Shin, Y. C.; Smith, R. P. 1999. Pooled mean group estimation if dynamic heterogeneous panels, Journal of the American Statistical Association 94: 621-634.

http://dx.doi.org/10.1080/01621459.1999.10474156

Plummer, M. G. 2009. ASEAN economic integration: trade, foreign direct investment, and finance. Singapore: World Scientific Publishing Co. Pte. Ltd.

Sauramo, P. 2008. Does outward foreign direct investment reduce domestic investment? Macroevidence from Finland, Discussion Papers, No.239. Labour Institute for Economic Research, Helsinki. 
Stevens, G. V. G.; Lipsey, R. E. 1992. Interactions between domestic and foreign investment, Journal of International Money and Finance 11: 40-62.

http://dx.doi.org/10.1016/0261-5606(92)90020-X

UNCTAD. 2011. World investment report 2011: nob-equity modes of international production and development. United Nations, New York and Geneva.

UNCTAD. 2012. World investment report 2012: towards a new generation of investment policies. United Nations, New York and Geneva.

UNCTAD. 2013. World investment report 2012: global value chains: investment and trade for development. United Nations, New York and Geneva.

UNCTADstat. 2014. [online], [cited 9 September 2014]. Available from Internet: https://macrofinance .nipfp.org.in/PDF/02_6Pr_Patnaik_GPS2010_version3.pdf

Wong, K. N.; Goh, S. K. 2011. Outward FDI, merchandise and services trade: evidence from Singapore, MPRA Paper, No.35377. University Library of Munich, Germany.

Bee Wah TAN is a PhD student at Universiti Sains Malaysia, Penang, Malaysia. Her research interests are development economics and FDI. She has several publications in international refereed journals.

Soo Khoon GOH is currently attached to Universiti Sains Malaysia, Penang, Malaysia. Her research interests are macroeconomics and international economics. She has published in various international refereed journals.

Koi Nyen WONG is Associate Dean and Professor of Economics at the Business School, Sunway University, Malaysia. His research focuses on FDI and international trade, and he publishes in international refereed journals. 